\title{
नेपाली बृहत् शब्दकोशका शीर्षशब्दमा वैकल्पिक प्रविष्टिको सान्दर्भिकता
}

\author{
राजेन्द्र खनाल \\ sauravabhirk@gmail.com \\ उप्राध्यापक \\ शिक्षाशास्त्र केन्द्रीय विभाग, त्रि.वि., कीर्तिपुर
}

\begin{abstract}
लेखसार
नेपाली बहहत् शब्दकोशमा प्रविष्ट शीर्षशब्दमा गरिएको वैकल्पिक प्रविष्टिप्रति विद्यार्थीहरूको प्रतिक्रिया लिई विकल्पमध्ये शीर्षीकरण गर्न उपयुक्त मान्न सकिने शीर्ष शब्द सुकाउने उद्देश्यमा केन्द्रित रही प्रस्तुत लेख तयार पारिएको छ। नेपाली शिक्षा विषयमा स्नातकोत्तर तहमा अध्ययनरत प० जना विद्यार्थीलाई नमुनाका रूपमा लिई उनीहरूको प्रतिक्रिया तथा कोश सम्पादन प्रक्रियाको सैद्धान्तिक मान्यतालाई आधार बनाई प्रस्तुत लेख तयार पारिएको छ। प्रस्तुत लेखमा नेपाली बृहत् शब्दकोशमा वैकल्पिक प्रविष्टि दिइएका शब्दप्रति नमुना विद्यार्थीवाट प्राप्त प्रतिक्रियाको प्रतिशताड्कको गणनाका आधारमा विश्लेषण गरिएको छ। नमुना विद्यार्थीवाट शतप्रतिशत सकारात्मक अभिमत प्राप्त भएका आठ ओटा शब्द उपियाँ, छात्रावास, धसिड्गर, नाउर, पाउजु, बाइबल, रेकर्ड र सरिता रहेका छन भने असी प्रतिशत वा सोभन्दा बढी प्रतिशतले सकारात्मक प्रतिक्रिया जनाएका अगेनो, अधिगमन, अनिच्छुक, अन्तर्मुखी, अप्ठयारो, उल्फा, किचिमिची, खच्चड, छानो, जेब, नवरात्री, नसिब, भक्कानो, भक्त, यष्टि, राडो, रोमावली र सरिफ रहेका छन् । ठेट्नो, गुलाब, मतपेटिका, धपेडी, धर्माध्यक्ष तथा अखानो शब्दलाई निर्विकल्प शीर्षशब्द बनाउनुपईई भन्ने अभिमत असी प्रतिशतभन्दा कम र पैंसट्ठी प्रतिशतभन्दा माथि रहेको छ भने दुई शब्दमध्ये एकलाई मात्र शीर्ष बनाउनुपई भन्ने अभिमतको प्रतिशत अन्तर $P Y$ र सोभन्दा कम भएका जम्मा आठ जोडी शब्द रहेका छन् : अधिदेव/अधिदेवता, उछ्छितो/उछ्छितो, उलटपलट/उलटपुलट, नसियत/नसिहत, पट्याड्ग/पट्याड्ड; पथ्रेन/पथ्यान, परमार्द्ध/परमार्ध र मसोट/मसौट / यस अध्ययनबाट शब्दकोशमा निर्विकल्प शब्द चयन गरी प्रविष्ट गर्नुपर्ने निष्कर्ष प्राप्त भएको छ। जुनसुकै भाषामा पनि विविध आधारमा शब्दगत भेद भए पनि मानक रूप एडटा बनाउन सक्नुपई । त्यसो भएमा मात्र भाषाको स्तरीकरण तथा मानकीकरण हुँदै जान्छ। त्यस्तै, शब्दकोशको सुन्दरता र उपयुक्तताका लागि पनि शीर्षशब्दका विकल्पहरू घटाउँदै लैजानु भाषाशास्त्रीय र कोशशास्त्रीय दृष्टिले पनि महत्त्वपूर्ण मानिने हुनाले एउटा मात्र शब्दलाई नै प्रविष्टिमा राखुपुई वैकल्पिक शब्दलाई अर्थनिर्देश गरेर वा प्रतिनिर्देश गरेर प्रस्टयाउनु उपयुक्त हुन्छ।
\end{abstract}

शब्दकुन्जी : शब्दकोश, शीर्षशब्द, प्रविष्टि, शीर्षीकरण, प्राथमिकता। 


\section{विषयप्रवेश}

सामान्य शब्दमा कोश भन्नाले सड्ग्रह वा भण्डार बुभिन्छ। सामान्य क्षेत्रमा ढुकुटी र भाषामा शब्दभण्डारको अर्थ कोशबाट ग्रहण गर्न सकिन्छ। 'कुश्' शब्दमा 'अच्' प्रत्यय लागेर कोश शब्द व्युत्पन्न भएको हो। 'कुश्' भन्नाले ऋग्वेदमा सुनले बनेको धातु, रघुवंशमा रुपैयाँ वा सम्पत्ति, कादम्बरीमा सड्ग्रह वा खजानालाई जनाइन्थ्यो (पौडेल, २०६९, पृ. ६१)। कोश भाषा साहित्यमा शब्द, इतिहास, सूचना आदिको सड्कलन र शब्दकोशमा शब्दको परिभाषा, पर्याय, विपर्याय, अर्थ, व्याख्या आदिसहितको सड्कलन स्वरूप हो। 'कोश' लाई अड्ग्रेजी भाषामा डिक्सनरी (Dictionary) भनिन्छ। डिक्सनरी शब्दले शब्दहरूको भण्डारलाई जनाउँछ। अड्ग्रेजी भाषाको Lexicology शब्दको नेपाली रूपान्तरण नै कोशविज्ञान हो । Lesxis र Logy को समन्वयबाट Lexicology शब्दको निर्माण भएको हो । अंग्रेजी भाषामा Lexis \Lexicon को अर्थ 'शब्द' र $\operatorname{logy}$ को अर्थ 'अध्ययन' हुने भएकाले Lexicology शब्दको व्युत्पत्तिगत अर्थ 'शब्दको अध्ययन गर्ने विज्ञान' हो (खनाल, २०७६, पृ. ९ू)। व्युत्पत्तिका आधारमा कोशविज्ञानको अर्थ 'शब्दको अध्ययन गर्ने विज्ञान' भए पनि व्यापक सन्दर्भमा कोशविज्ञान भन्नाले कोशानिर्माणसंग सम्बन्धित सम्पूर्ण सैद्धान्तिक पक्षको अध्ययन गर्ने शास्त्र मानिन्छ । कोशविज्ञान प्रायोगिक भाषाविज्ञानको अत्यन्त विकसित शाखा मानिएको छ, तथापि यो प्रायोगिक भाषाविज्ञानमा मात्र सीमित शाखा भने होइन। सामान्यतः कोशविज्ञानले कोशको निर्माण, कोशको विश्लेषण तथा उपयोगसम्बन्धी शास्त्रलाई जनाउँछ। विशिष्ट अर्थमा भाषाका शब्दहरूको अर्थ, संरचना, अर्थसम्बन्ध, स्रोत व्युत्पत्ति, शब्दहरूको ऋम आदिको वैज्ञानिक ढड़ले भण्डार गर्ने विज्ञानलाई कोशविज्ञान भनिन्छ, ।

कोशविज्ञानका माध्यमबाट कोशनिर्माण गर्ने विधिका साथसाथै विभिन्न भाषा, व्यक्तित्व, साहित्य आदिको जानकारी लिन सहयोग पुग्छ । प्रायोगिक भाषाविज्ञानको एउटा महत्त्वपूर्ण शाखाका रूपमा रहेको कोशविज्ञानबाट विभिन्न शब्दहरूको अर्थ, शब्दको स्रोत, व्युत्पत्ति आदि बारेमा थाहा हुन्छ। कुनै पनि शब्दको ह्रस्व-दीर्घ, अक्षर संरचना आदिलाई प्रष्ट पार्ने काम कोशविज्ञानले गर्दछ। त्यसैगरी भाषिक उच्चारणको प्रचलित नियमलाई बुऊन, शब्दको व्युत्पत्ति र स्रोत थाहा पाउन, शब्दको मूल रूप र गाँसिएका रूपहरूलाई पहिल्याउन, भाषासँग सम्बन्धित बोध र अभिव्यक्ति कलाको विकास गर्न कोशविज्ञानले महत्त्वपूर्ण सघाउ पुच्याउँछ।

प्रस्तुत लेखमा कोश सम्पादनका प्रक्रियामा शीर्षशब्दको प्रविष्टि वा शीर्षीकरणका आधारसहित सैद्धान्तिक स्वरूप केलाइएको छ। त्यस्तै, वैकल्पिक प्रस्तुति दिइएका शीर्षशब्दका प्रतिनिधिमूलक शब्द चयन गरी तिनको शीर्ष (एउटा) शब्द निर्धारणका लागि स्नातकोत्तर तहमा अध्ययनरत विद्यार्थीहरूको प्रतिक्रियाका आधारमा निष्कर्ष निकाली सुभावसमेत समावेश गरी यो लेख तयार पारिएको छ।

\section{अध्ययनको सान्दर्भिकता}

प्रत्येक भाषामा विविधता रहेकै हुन्छु् । भाषालाई सर्वसम्प्रेष्य बनाउनु नै सर्वस्विकार्य बनाउनु हो। यसका निम्ति भाषाको स्वरूप तथा संरचना परिष्कृत हुनुपर्दछ। भाषिक परिष्कार र मानकीकरणका निम्ति लामो समय लाग्छ। भाषाको मानकीकरण तथा स्तरीकरणमा शब्दकोशले अहम् भूमिका खेलेको हुन्छ। भाषालाई एकरूप, मानक तथा स्तरीय बनाउनका निम्ति शब्दकोशको उपयोग नै प्रामाणिक समाधान हो। तसर्थ कोशकारले कोश निर्माण गर्दा उपर्युक्त पक्षमा विशेष ध्यान दिनुपर्दछ, यद्यपि कोशको प्रयोजन 
नेपाली बृहत् शब्दकोशका शीर्षशब्दमा वैकल्पिक प्रविष्टिको सान्दर्भिकता / 127

तथा उद्देश्यले पनि प्रकृतिलाई निर्धारण गर्दछ। नेपालमा नेपाली भाषासम्बद्ध कोशको परम्परा पुरानै छ। नेपालको आधिकारिक कोश नेपाली बृहत् कोशको संस्थागत स्थापना र प्रकाशन भएको करिब चालिस वर्ष बितिसक्दा पनि शब्दको शीर्षीकरण वा शीर्षशब्दको प्रस्तुतिमा स्पष्ट दिशा अवलम्बन गर्न नसकेको हो कि भन्ने प्रमाण शीर्षशब्दमा दिइएका वैकल्पिक प्रविष्टिको बढोत्तरीले पुष्टि गर्दछ। शीर्ष शब्दमा वैकल्पिक प्रविष्टि दिनु एक प्रकारको अपरिपक्वता हो, निर्णय गर्न नसक्नु हो, मानक स्वरूप पर्गेल्न नसक्नु हो भन्न सङ्कोच छैन ।

विश्वका सर्वस्विकार्य शब्दकोश (अलि, १९९६ र व्म्मर, मेकोन्टस एन्ड टर्नबुल, २००४) मा यस्तो प्रयोग तथा प्रस्तुति पाइंदैन । यसबाट मानक तथा स्तरीय शब्दकोशका शब्दमा वैकल्पिक प्रविष्टि गर्न नसकिने प्रस्ट हुन्छ। यसका अतिरिक्त नेपाली बृहत् शब्दकोशमा यस्ता शब्द घट्दै जानुको सट्टा बढ्दै गएका (नेपाल प्रज्ञा प्रतिष्ठान, २०५५ र नेपाल प्रज्ञा प्रतिष्ठान २०७५) छन्। यसले नेपाली भाषाको मानकीकरण र स्तरीकरणका निम्ति कन समस्या बढाउँदै जाने सम्भावना देखिन्छ। तसर्थ यस्ता वैकल्पिक शब्दमध्ये कुन शब्द शीर्ष बनाउनु उपयुक्त होला भनी नेपाली शिक्षामा स्नातकोत्तर गरिरहेका विद्यार्थीलाई बन्द मतावली दिई प्रतिक्रिया लिई त्यसका आधारमा विश्लेषण र निष्कर्ष निकालिएको छ। तसर्थ प्रस्तुत लेखको सहयोगले नेपाली भाषामा वैकल्पिक प्रविष्टि दिइएका शब्दमध्ये एउटा (शीर्ष) उपयुक्त शब्द छनोट गरी मानक र स्तरीकरण गर्न टेवा पुन्याउन सक्छ। यो लेख कोशकार तथा कोशका उपयोगकर्तालाई उपयोगी त हुने छ नै साथै कोश सम्पादन प्रक्रियासम्बन्धमा सहयोगी बन्ने छ। त्यस्तै, अनुसन्धानका निम्ति पनि नयाँ जिज्ञासासमेत पैदा गर्ने देखिन्छ। नेपाली भाषालाई सर्वस्विकार्य बनाउने दिशामा यस्ता अनुसन्धान आवश्यक पर्ने भएकाले यस लेखको सान्दर्भिकता पुष्टि हुन्छ।

\section{अध्ययनको उद्देश्य}

नेपाली बृहत् शब्दकोशमा प्रस्तुत शीर्षशब्दमा गरिएको वैकल्पिक प्रविष्टिमध्ये शीर्षीकरण गर्न उपयुक्त हुने एउटा शब्द पहिचान गर्नु यस लेखको प्रमुख उद्देश्य हो। कोश सम्पादन प्रक्रियामा शीर्षशब्द चयनका सैद्धान्तिक स्वरूप प्रस्तुत गर्नु, शीर्षशब्द निर्धारण र चयनका निम्ति आवश्यक निष्कर्ष निकाल्नु यस लेखका विशिष्ट उद्देश्यहरू हुन् ।

\section{अध्ययन विधि र प्रक्रिया}

प्रस्तुत लेखको ढाँचा मूलतः गुणात्मक प्रकृतिको छ। प्रस्तुतिमा वर्णनात्मक विधि अपनाइएको छ। सामग्री सड्कलनमा क्षेत्रीय सर्वेक्षण विधि र पुस्तकालयीय अध्ययन प्रक्रिया अपनाइएको छ। अध्ययनमा साङ्खिकीय तथ्याङ्कको उपयोग तथा सन्दर्भपरक कोशवैज्ञानिक विश्लेषण समेत गरिएको छ। गुणात्मक अनुसन्धानमा प्रतिनिधिमूलकभन्दा पनि अध्ययनको उद्देश्यलाई पूरा गर्न छानिएका व्यक्तिहरू नमुनाका रूपमा रहेका हुन्छन् (खनाल, २०७७, प्. १२९)। यस अध्ययनमा कोशशास्त्रीय अध्ययन गरिरहेका र नेपाली शब्दभण्डारको सुरुचिपूर्ण अध्ययन गर्ने नेपाली शिक्षाका स्नातकोत्तर तहका विद्यार्थी नुमनाका रूपमा लिनु सार्थक ठानिएकाले असम्भावनात्मक नमुना छनोट प्रक्रिया अपनाइएको छ। प्रस्तुत आलेखमा त्रिविअन्तर्गतको शिक्षाशास्त्र केन्द्रीय विभाग, नेपाली शिक्षा विषयका प० जना विद्यार्थी नमुनाका रूपमा रहेका छन् । त्यस्तै, नेपाली बृहत् शब्दकोश २०७४ मा वैकल्पिक प्रविष्टि दिइएका प्रतिनिधिमूलक ४० ओटा शब्दमा विद्यार्थीको प्रतिक्रिया लिई उक्त प्रतिक्रियाका आधारमा विश्लेषण गरिएको छ। 


\section{कोश सम्पादन प्रक्रिया}

कोश निर्माण वा सम्पादन एक जटिल कार्य हो । कोश सम्पादन अत्यन्त साधनामय, गौरवमय र गम्भीर कार्य हो (लम्साल, २०४७, प्. ९५) । शब्दकोशमा कोश निर्माण र प्रयोक्ताका आवश्यकता र प्रयोगअनुसारका आशा गरेका शब्दसम्बन्धी ज्ञानका कुरा सङुलित हुन्छन्। त्यसैले सुव्यवस्थित ढड़ले कोश बनाउने वा सम्पादन गर्ने प्रक्रियालाई नै कोश निर्माण तथा सम्पादन प्रक्रिया भनिन्छ। यो ज्यादै कठिन कार्य भएको हुँदा यसका लागि व्यक्तिगत धैर्यता, समर्पण र संस्थागत एवम् निरन्तर प्रयास हुनु आवश्यक मानिन्छ। कोशलाई निर्माण वा सम्पादन गर्दा मूलतः तीन चरणहरू अपनाइन्छ।

कोश सम्पादनको पहिलो चरण कोश निर्माणको आरम्भ चरण हो। यस चरणमा कोश निर्माणका लागि योजना, सामग्री सड़लन, प्रविष्टि चयन आदि जस्ता कार्य गरिन्छ (लम्साल, २०४५७, पृ. ९६)।

9) योजना निर्माण : कुनै पनि कार्य सुव्यवस्थित ढड्रले गर्नका लागि योजनाको आवश्यकता पर्दछ, । कोश निर्माण कार्य एक जटिल कार्य भएकाले यसको निर्माण गर्दा आवश्यक पर्ने पूर्व तयारीका कुराहरू यसअन्तर्गत पर्दछन् । कोश निर्माणसम्बन्धी योजना तयार गर्दा त्यसमा लाग्ने आर्थिक पक्षका साथै कुन प्रकारको, कस्तो स्वरूपको, कुन भाषाको, कुन भौगोलिक क्षेत्रको कोश निर्माण गर्ने, सामग्री कसरी सङ्कलन गर्नेजस्ता कुरामा केन्द्रित भएर योजना निर्माण गरी छनोट, व्यवस्थापन र प्रस्तुतीकरण आदि पक्षमा समेत विशेष ध्यान पुच्याउनु पर्ने हुन्छ।

२) सामग्री सड्कलन : कोश निर्माणका लागि सामग्री सङ्कलन महत्त्वपूर्ण र प्रमुख कार्य हो। कोशको प्रकृति हेरी त्यसका निम्ति मौखिक र लिखित भाषाका माध्यमबाट सामग्री सङ्कलन गर्नुपर्दछ,। लिखित सामग्रीबाट शब्द सङ्कलन गर्दा लिखित साहित्यका सबै किसिमका ग्रन्थ, कृति, पुस्तक, समाचारपत्र आदिका माध्यमबाट सड्कलन गर्नुपर्दछ। सामग्री सड्कलन गर्दा सर्वप्रथम ३/४" को आकारप्रकार भएको कागज निर्माण गरी शब्दको सन्दर्भलाई खुलाएर वर्णानुक्रमका आधारमा उद्वरणसहित टिप्नुपर्दछ (पौडेल, २०६९, पृ. ५६)। त्यसपछि, टिपिएका सामग्रीहरूको प्रयोग सन्दर्भ र नाम ठेगाना प्रस्ट उल्लेख गर्नुपर्दछ। शब्द टिप्ने सन्दर्भमा छपाइमा देखिएका कमीकमजोरीलाई सच्याएर मात्र टिप्नुपर्दछ। वर्णानुक्रमका आधारमा ऋमबद्ध रूपमा मिलाएर राखेका शब्द सामग्रीलाई ठुलो आकारको कागजमा एउटा शब्दको सूचना, सन्दर्भ र विवरणलाई समेटेर उतार्नुपर्दछ। यसरी योजना र निश्चित नियमको परिधिमा केन्द्रित रहेर कोशसम्पादनका लागि सामग्री सङ्कलन गर्नु आवश्यक हुन्छ। ठिक ढड़ले सामग्री सड्कलन र व्यवस्थापन भइसकेपछि, प्रविष्टि चयन गर्न लायक बन्छ।

३) प्रविष्टि चयन : प्रविष्टि त्यो शाब्दिक एकाइ हो जसलाई कोशमा प्रवेश गराइन्छ, (लम्साल, २०४४७, प्. १०३)। प्रविष्टिलाई कोशीय एकाइ वा कोशिम पनि भनिन्छ। प्रविष्टि चयन गर्दा विभिन्न स्रोतबाट सड्कलन भएका शब्दलाई हुबहु कोशमा समावेश नगराई कोशमा प्रवेश गराइने एकाइको छनोट गर्नु राम्रो हुन्छ। प्रविष्टि चयन गर्दा त्यस कोशको प्रयोगकर्ता को को हुन सक्छन् भन्ने कुरालाई ध्यानमा राखी कोशमा प्रचलित शब्द, नवप्रचलित शब्द, लुप्त शब्द, पारिभाषिक तथा प्राविधिक शब्द, व्यक्तिवाचक शब्द, रिक्त शब्द, प्रत्यय, विभक्ति आदिलाई आवश्यकताअनुसार छनोट गरी प्रवेश गराउनुपर्दछ। प्रविष्टि चयनका सन्दर्भमा निम्नलिखित कुराहरूमा विशेष ध्यान पुच्याउनुपर्दछ (खनाल, २०७६, पृ. १९४) : 
अ) प्रचलित शब्द : सम्बन्धित भाषाका बहुप्रचलित शब्दहरूले शब्दकोशको प्रविष्टि चयनमा सबभन्दा बढी प्राथमिकता पाउने गई्छ् ।

आ) अभिनव शब्द : सिर्जनात्मक स्वरूप वा आदानात्मक प्रवृत्तिद्वारा विकसित भई सम्बन्धित वक्ताद्वारा नवीनता अनुभूत र अनुस्यूत शब्दलाई अभिनव शब्द भनिन्छ, (लम्साल, २०पू७, पृ. १०४)। समाज, संस्कति, भाषा, प्रविधि, साहित्य आदि क्षेत्रमा नवप्रचलनमा रहेका शब्दलाई कोशमा प्रविष्टि दिनुपर्दछ।

इ) परिभाषिक-प्राविधिक शब्द : विज्ञान, कला, शिल्प, प्रविधि तथा बहुप्रविधि आदि क्षेत्रसँग सम्बन्धित विशेष अर्थ भएका शब्द नै प्राविधिक शब्द हुन् । सबै प्राविधिक शब्दहरू साधारण कोशमा समावेश गर्नु हुँदैन। विशिष्टताको मात्र अधिक भएका शब्दहरू विशिष्ट कोशमै अपेक्षित हुन्छन्। सर्वमान्यताको मात्रा अधिक भएका शब्दहरू सामान्य कोशमै अपेक्षित हुन्छन्।

ई) रिक्त शब्द : छुट्टै प्रयोग नहुने तर कुनै भाषिक संरचनामा भने आउने शब्दलाई रिक्त शब्द भन्न सकिन्छ (लम्साल, २०४७, प्. १०४)। स्वतन्त्र प्रयोग नहुने तर शब्दांशको संरचनामा आउने शब्दहरू रिक्त शब्दका नामले चिनिन्छन् । यस्ता शब्दहरूलाई कोशमा प्रायः सन्निहित शब्दसँग राखिन्छ र मूल प्रविष्टि वा शीर्षशब्दमा राख्दा चाहिं प्रतिनिर्देश गरिन्छ, तथापि यस्ता शब्दहरू स्वयम्मा अर्थवान् नहुनाले कोशको प्रयोजनअनुरूप ध्यान दिनु उपयुक्त हुन्छ।

उ) सम्बन्धपरक शब्द : यो कुनै वस्तु वा सूच्य निर्देश नगर्ने शब्द हो। यसलाई प्रकार्यात्मक वा व्याकरणात्मक शब्द पनि भन्न सकिन्छ (लम्साल, २०४७, प्. १०४)। विभक्ति चिह्न र संयोजकलाई सम्बन्धपरक शब्द भनिन्छ। यस्ता शब्दहरूको प्रयोग विभिन्न सन्दर्भ र प्रसड्गमा आवश्यकताअनुसार हुने गर्दछ। वस्तुपरकभन्दा पनि बढी प्रयोग सम्बन्धपरक शब्दहरूको हुने गर्दछ। त्यसैले शब्दकोश निर्माणका सन्दर्भमा यस किसिमका शब्दलाई पनि प्रवेश दिनु आवश्यक हुन्छ।

ऊ) समस्त शब्द : दुई वा दुईभन्दा बढी शब्दलाई अर्थ नबिग्रने गरी एउटै बनाउने प्रक्रिया समास हो । समास भएका शब्दलाई समस्त शब्द भनिन्छ। समस्त शब्दलाई पनि शब्दकोशमा प्रविष्टि गराउनु पर्दछ।

ए) व्यक्तिवाचक शब्द : कुनै पनि व्यक्तिको परिचय दिने शब्दलाई नै व्यक्तिवाचक शब्द भनिन्छ। व्यक्ति विशेष वा स्थान विशेषका नाममध्ये विषयवस्तुका रूपमा भाषामा प्रयोग हुने शब्दहरू समावेश्य ठहरिन्छन्। जस्तै- कृष्ण, लुम्बिनी।

ऐ) सड्क्षेप शब्द : धेरै चलन चल्तीका सड्घ, संस्था र कार्यहरूको नामलाई सड्क्षेपमा प्रयोग गरिन्छ भने कतिपय सन्दर्भमा सरलता र सङ्केतका लागि यस्ता शब्द प्रयुक्त हुन्छन्। जस्तै- गो. प., त्रि. वि., रा. स. स.। 
ओ) उखान-टुक्का र उद्धरण : कुनै भाषाको मौलिकतालाई जनाउने उखान-टुक्कामा सूच्य अर्थभन्दा विशिष्ट अर्थ व्यक्त गर्ने शक्ति रहेको हुन्छ। यस्ता भाषिक विधिलाई विशेष (उखान-टुक्का) कोशमा बाहेक अन्य कोशमा बेग्लै प्रविष्टि नदिई गौण प्रविष्टिमा राखिएको हुन्छ।

औ) निपात : निपातहरू स्वतन्त्र वा कोशीय शब्द होइनन् तथापि भाषामा मिठास थप्न यस्ता शब्दहरू प्रयुक्त हुन्छन् । स्वतन्त्र अर्थ नभएकाले नै यस्ता शब्दको कोशीय प्रविष्टिमा प्रश्न उठ्न सक्छ। तथापि यस्ता शब्दले प्रयोगका सन्दर्भमा विलक्षण र विशेष अर्थसमेत व्यक्त गर्ने हुँदा यिनलाई पृथक प्रविष्टि दिइनु पर्दछ।

अं) वैकल्पिक शब्द : कतिपय शब्दकोशमा अर्थ उही भएर पनि एउटा शब्दका एकभन्दा बढ़ी वैकल्पिक रूपहरू प्रचलित हुन्छन् । यस्तो स्थिति उच्चारण वा वर्णविन्यासको भिन्नता वा दुवैको भिन्नताबाट उत्पन्न हुन्छ (अधिकारी, २०६२, पृ. २१६)। बहुप्रचलित शब्दहरूमा यस्तो अवस्था देखियो भने तिनीहरूको भिन्नै प्रविष्टि दिनुपछ। यसो गर्दा शब्दको भिन्न महत्ता रहन्छ र पहिचान पनि हुन्छ।

\section{प्रविष्टिमा विकल्पको औचित्य}

शब्दकोशका शीर्षशब्दमा दिइने वैकल्पिक प्रविष्टिका सम्बन्धमा अधिकारी (२०६२) भन्छन् : मानकको स्थिरीकरण भइनसकेका भाषाहरूमा यस किसिमको वैकल्पिक प्रविष्टि अक आवश्यक हुन्छ तर मानकीकरणलाई बढावा दिन यस्ता विकल्पहरूमध्ये कुनै एकको छनोट गर्ने कुरालाई बढ़ी महत्त्व दिंदै जानु उचित हुन्छ। नत्र विकल्पको भरमारले कोशलाई नै भद्दा बनाइदिने डर हुन्छ। तसर्थ वैकल्पिक प्रविष्टिलाई न्यूनीकरण गर्नु पनि मानक कोशनिर्माणको एउटा महत्त्वपूर्ण पक्ष हो (अधिकारी, २०६२, पृ. २१७)। माथिको सन्दर्भवाट प्रस्ट हुन्छ कि भाषाको स्तरीकरण तथा मानकीकरणका निम्ति मात्र होइन शब्दकोशको सुन्दरता र उपयुक्तताका लागि पनि शीर्षशब्दका विकल्पहरू घटाउँदै लैजानुपछ। हो, एउटा भाषाका विविधतामा रहेका उत्तिकै महत्त्वका शब्दको पहिचान स्थापित गर्न र मूल वा शीर्षशब्द निर्क्योल गर्न कठिन भएको अवस्थामा वैकल्पिक प्रविष्टिले स्थान पाउनु स्वाभाविकै हो। नेपाली भाषाका सन्दर्भमा स्तरीकरण बनाउंदै लैजानुको साटो आगन्तुक शब्दलाई समेत कनपछि कन वैकल्पिक प्रविष्टि दिनु सारतः औचित्यपूर्ण नहुन सक्छ। प्रयोगात्मक नेपाली शब्दकोश २०६१ मा अत्यन्त न्यून सड्ख्यामा यस्ता वैकल्पिक शब्द समावेश गरिएको छ भने नेपाली बृहत् शब्दकोश २०४० का तुलनामा २०७४ सालमा यस्ता शब्दको अभ बढोत्तरी हुनु कोशशास्त्रीय र भाषाको स्तरीकरणको मूल्यअनुसार पनि अस्वाभाविक देखिन्छ। तसर्थ प्रस्तुत अध्ययनको सहयोगबाट वैकल्पिक शीर्षशब्दको न्यूनीकरणमा टेवा मिलोस् भन्ने अपेक्षा गरिएको छ।

\section{परिणाम तथा विश्लेषण}

नेपाली बृहत् शब्दकोशमा वैकल्पिक प्रविष्टिसहित प्रस्तुत गरिएका शब्दमध्ये उपयुक्त शीर्षशब्द सम्बन्धमा प०० जना विद्यार्थीबाट प्राप्त प्रतिक्रिया यसप्रकार छ : 
नेपाली बृहत् शब्दकोशका शीर्षशब्दमा वैकल्पिक प्रविष्टिको सान्दर्भिकता / 131

तालिका नं. 9

\begin{tabular}{|c|c|c|c|c|}
\hline क.सं. & शब्द & प्रतिक्रिया & शब्द & प्रतिक्रिया \\
\hline 9 & अखान & q७ & अखानो & ३३ \\
\hline 2 & अगेन & 90 & अगेनो & ૪০ \\
\hline ३ & अधिगम & $\gamma$ & ऋधिगमन & $\gamma \xi$ \\
\hline$\gamma$ & अधिदेव & $2 \bar{c}$ & अधिदेवता & २२ \\
\hline$y$ & अनिच्छु & $\gamma$ & अनिच्छुक & ૪६ \\
\hline$\xi$ & अन्तर्मूख & $y$ & अन्तर्मुखी & $\gamma y$ \\
\hline 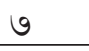 & अप्ठेरो & $\overline{5}$ & अप्ठयारो & ४२ \\
\hline$\overline{5}$ & उछितो & $2 y$ & उछि,त्तो & $2 y$ \\
\hline$\rho$ & उपिङँ & 0 & उपियाँ & yo \\
\hline 90 & उलटपलट & २० & उलटपलट & ३० \\
\hline 99 & उल्फत & $\vartheta$ & उल्फा & ૪३ \\
\hline 92 & किचिपिची & $\gamma$ & किचिमिची & ૪६ \\
\hline $9 ३$ & खच्चड & ૪০ & खच्चर & 90 \\
\hline 98 & गुलाफ & $9 y$ & गुलाब & ३ू \\
\hline 94 & छात्रालय & 0 & छात्रावास & yo \\
\hline $9 \xi$ & छान & 2 & छानो & $\gamma \bar{\zeta}$ \\
\hline q७ & जेप & ३ & जेब & ૪৩ \\
\hline 95 & ठेटनु & 98 & ठेटनो & ३६ \\
\hline 99 & धपेडी & ३४ & धपेरी & $9 y$ \\
\hline २० & धर्माधिकृत & $q \vartheta$ & धर्माध्यक्ष & ३३ \\
\hline २१ & धसिँगर & 0 & धसिड़गर & yo \\
\hline २२ & नवरात्रि & 90 & नवरात्री & $\gamma O$ \\
\hline २३ & नसिप & $\gamma$ & नसिब & ૪६ \\
\hline २४ & नसियत & २२ & नसिहत & $2 \bar{c}$ \\
\hline $2 y$ & नाउर & yo & नाउरु & 0 \\
\hline २६ & पड्याड़गग & 29 & पड्याड़्ड & २१ \\
\hline २७ & पथ्रेन & २२ & पथ्य्रान & २द \\
\hline 25 & पाउजु & yo & पाउजेब & 0 \\
\hline 29 & प्रथमार्द्ध & २० & प्रथमार्ध & ३० \\
\hline ३० & बाइबल & yo & बाइबिल & 0 \\
\hline ३१ & भक्कानु & $\bar{\sigma}$ & भक्कानो & ४२ \\
\hline ३२ & भक्त & ૪૦ & भक्त & 90 \\
\hline ३३ & मतपेटिका & $\xi y$ & मतपेटी & $9 y$ \\
\hline ३૪ & मसोट & ३० & मसौट & 20 \\
\hline ३ू & यष्टि & ૪০ & यष्टी & 90 \\
\hline ३६ & राडो & ૪૪ & राढो & $\xi$ \\
\hline ३৩ & रेकड & 0 & रेकर्ड & yo \\
\hline ३५ & रोमावलि & $\vartheta$ & रोमावली & ૪३ \\
\hline ३९ & सरित् & 0 & सरिता & yo \\
\hline ૪о & सरिप & 90 & सरिफ & ૪O \\
\hline
\end{tabular}

स्रोत : स्थलगत सर्वेक्षण, २०७६ 
माथिको तथ्याङ्कका आधारमा वैकल्पिक प्रविष्टि दिइएका विभिन्न शब्दमध्ये केही शब्दका विकल्पको सान्दर्भिकता नै नभएको देखिन्छ। शतप्रतिशत सकारात्मक प्रतिक्रिया आएका शब्द निर्विकल्प हुन् भन्नु अत्युक्ति नहोला। $० ०$ प्रतिशतदेखि माथि सकारात्मक प्रतिक्रिया आएका शब्दलाई पनि सोचनीय मान्नुपर्दैन । ५० प्रतिशतदेखि कम सकारात्मक प्रतिक्रिया आएका शब्दका बारेमा थप अध्ययन तथा पुनरवलोकन गरी निर्विकल्प बनाउन सकेको खण्डमा वैकल्पिक प्रविष्टिको विस्तारै न्यूनीकरण गर्न सकिन्छ भन्ने अध्येताको निष्कर्ष छ।

अध्ययनबाट प्राप्त प्रतिक्रियाका आधारमा निर्विकल्प भन्न सकिने शब्द निम्नानुसार रहेका छन् :

तालिका नं. २

\begin{tabular}{|l|l|l|l|l|l|l|l|}
\hline उपियाँ & छात्रावास & धसिझ्गर & नाउर & पाउजु & बाइबल & रेकर्ड & सरिता \\
\hline
\end{tabular}

उपर्युक्त आठ ओटा शब्द अधिक प्रचलन रहेका शब्द पनि हुन् । यी सबै नाम वर्गका शब्द हुन् । पचास जना नमुना जनसड्ख्यामध्ये कुनै एक जनाले पनि उक्त शब्दको विकल्प उपयुक्त छ भन्नेमा प्रतिक्रिया जनाएका छैनन् । यसबाट पुष्टि हुन्छ कि उपर्युक्त शब्दका विकल्पहरू क्रमशः उपिउँ, छात्रालय, धसिँगर, नाउरु, पाउजेब, बाइबिल, रेकड तथा सरित् शब्दलाई शीर्ष भूमिका दिनु वान्छनीय नभएको अभिमत प्रस्तुत अध्ययनबाट प्राप्त भएको छ।

अध्ययनमा समावेश गरिएका प्रतिनिधिमूलक वैकल्पिक शीर्षशब्दमध्ये ५० प्रतिशत र सोभन्दा बढी सकारात्मक प्रतिक्रिया आएका शब्दहरू यसप्रकार छन् :

तालिका नं. ३

\begin{tabular}{|c|c|}
\hline शब्द & प्रतिशत \\
\hline अगेनो & ᄃ० \\
\hline ऋधिगमन & $\rho 2$ \\
\hline अनिच्छुक & $\rho 2$ \\
\hline अन्तर्मखी & ९० \\
\hline अप्ठ्यारो & दर \\
\hline उल्फा & ᄃ६ \\
\hline किचिमिची & $\rho 2$ \\
\hline खच्चड & БO \\
\hline छानो & $\rho \xi$ \\
\hline जेब & ९४ \\
\hline नवरात्री & 50 \\
\hline नसिब & $\rho 2$ \\
\hline भक्कानो & $5 \gamma$ \\
\hline भक्त & 50 \\
\hline यष्टि & 50 \\
\hline राडो & दБ \\
\hline रोमावली & द६ \\
\hline सरिफ & 50 \\
\hline
\end{tabular}


माथिका अठार ओटा शब्द पनि विकल्पसहित शीर्षशब्दका रूपमा प्रविष्टि दिइनुको खासै सान्दर्भिकता देखिंदैन। छानो शब्दका पक्षमा ९६ प्रतिशत र जेब शब्दमा ९४ प्रतिशत अभिमत रहेको छ। त्यस्तै अधिगमन, अनिच्छुक, किचिमिची तथा नसिब शब्दका पक्षमा ९२ प्रतिशत अभिमत छ भने अन्तर्मुखी शब्दका पक्षमा ९० प्रतिशत अभिमत प्राप्त भएको छ। त्यस्तै, राडो शब्दमा द६, उल्फा तथा रोमावली शब्दमा ढ६ एवम् अप्ठ्यारो र भक्कानो शब्दमा ५ प प्रतिशत सकारात्मक अभिमत आएको छ। अगेनो, खच्चड, नवरात्री, भक्त, यष्टि तथा सरिफ शब्दलाई शीर्षशब्दका रूपमा निर्विकल्प प्रस्तुत गर्नुपर्दछ, भन्ने अभिमत ५० प्रतिशत रहेको छ। उक्त शब्दका विकल्पका रूपमा राखिएका शब्द कमशः अगेनु, अधिगम, अनिच्छु, अन्तर्मुख, अप्ठेरो, उल्फत, किचिपिची, खच्चर, छानु, जेप, नवरात्रि, नसिप, भक्कानु, भक्त, यष्टी, राढो, रोमावली र सरिप शब्दलाई शीर्षशब्दका रूपमा प्रविष्टि दिनुपर्दछ भन्ने अभिमत अत्यन्त न्यून मात्रामा प्राप्त भएको छ।

प्रस्तुत अध्ययनमा प्रतिनिधि शब्दका रूपमा लिइएका वैकल्पिक शीर्षशब्दमध्ये ७९ प्रतिशतभन्दा थौरै अनुपातमा प्रतिक्रिया प्राप्त भएका शब्दहरू यसप्रकार छन् :

तालिका नं. ช

\begin{tabular}{|c|c|c|c|c|}
\hline क.सं. & शब्द & प्रतिशत & शब्द & प्रतिशत \\
\hline 9 & अखानु & ३૪ & अखानो & $\xi \xi$ \\
\hline 2 & अधिदेव & पद & अधिदेवता & ૪૪ \\
\hline ३ & उछित्रो & yo & उछित्तो & yo \\
\hline$\gamma$ & उलटपलट & ૪૦ & उलटपुलट & $\xi ०$ \\
\hline$y$ & गुलाफ & ३० & गुलाब & ৩০ \\
\hline$\xi$ & ठेटन् & २द & ठेट्नो & ७२ \\
\hline$\vartheta$ & धपेडी & ৩০ & धपेरी & ३० \\
\hline $\bar{s}$ & धर्माधिकृत & ३४ & धर्माध्यक्ष & $\xi \xi$ \\
\hline$\rho$ & नसियत & ૪૪ & नसिहत & पद \\
\hline 90 & पड्याङ्ग & $y=$ & पड्याङ्.्ड & ४२ \\
\hline 99 & पश्रेन & ૪ & पथ्य्रान & पद \\
\hline 92 & प्रथमार्द्ध & ૪૦ & प्रथमार्ध & $\xi О$ \\
\hline १३ & मतपेटिका & ७০ & मतपेटी & ३० \\
\hline 98 & मसोट & ६० & मसौट & ૪о \\
\hline
\end{tabular}

माथिको तालिकामा दुई विकल्पमध्ये कुन उपयुक्त हुन्छ भन्ने मतावलीको प्रतिशत हेर्दा ठेट्नो शब्द ठेट्नु शब्दभन्दा बढी चयनयोग्य पाइएको छ। उक्त शब्दमा ठेट्नो शब्दका पक्षमा ७२ प्रतिशत मत प्राप्त भएको छ। गुलाफ भन्दा गुलाब शब्द र मतपेटी भन्दा मतपेटिका शब्द बढी चयनयोग्य भएको राय प्राप्त भएको छ। माथिका दुई जोडी शब्दमा गुलाब र मतपेटिका शब्दलाई निर्विकल्प बनाउनुपई भन्ने सन्दर्भमा ७० प्रतिशत प्रतिक्रिया आएको छ। धपेरी शब्दभन्दा धपेडी नै उपयुक्त हुन्छ भन्ने तथ्य पनि माथिको आँकडाले प्रस्ट्याउँछ। धर्माधिकृत शब्दभन्दा धर्माध्यक्ष तथा अखानु शब्दभन्दा अखानो शब्दतर्फ बढी मत प्राप्त भएको छ। मतावलीको अन्तर प्रतिशत २५ र सोभन्दा कम भएका शब्द थोरै मात्र छन् । 
प्रस्तुत अध्ययनमा समावेश गरिएका नमुना चालिस ओटा शब्दमध्ये शब्दकोशमा निर्विकल्प शीर्षीकरण वा प्राथमकिता साथ प्रविष्टि दिन सकिने गरी स्पष्ट निर्णय दिन मिल्ने शतप्रतिशत सकारात्मक प्रतिक्रिया आएका आठ ओटा शब्द र असी प्रतिशत वा सोभन्दा बढ़ी सकारात्मक प्रतिक्रिया आएका अठार ओटा शब्दलाई लिन सकिन्छ। त्यस्तै ६५ प्रतिशत वा सोभन्दा बढ़ी सकारात्मक प्रतिक्रिया आएका छ ओटा शब्द छन् भने बाँकी जम्मा आठ ओटा शब्दमा मात्र प्रतिक्रियाको अन्तर प्रतिशत २५ भन्दा कम छ।

\section{निचोड}

प्रस्तुत अध्ययनबाट प्राप्त भएको निष्कर्षलाई निम्नानुसार देखाइएको छ :

१. शतप्रतिशत चयन गर्न सकिने वा निर्विकल्प शीर्षशब्द हुनुपईई भन्ने शतप्रतिशत अभिमत प्राप्त भएका आठ ओटा शब्द उपियाँ, छात्रावास, धसिड्गर, नाउर, पाउजु, बाइबल, रेकर्ड र सरिता रहेका छन् ।

२. असी प्रतिशत वा सोभन्दा बढी प्रतिशतले अगेनो, अधिगमन, अनिच्छुक, अन्तर्मुखी, अप्ठ्यारो, उल्फा, किचिमिची, खच्चड, छानो, जेब, नवरात्री, नसिब, भक्कानो, भक्त, यष्टि, राडो, रोमावली, सरिफ शब्दलाई निर्विकल्प शीर्षशब्द बनाउनुपई भन्ने अभिमत प्रकट गरेको पाइयो।

३. ठेट्नो, गुलाब, मतपेटिका, धपेडी, धर्माध्यक्ष तथा अखानो शब्दलाई निर्विकल्प शीर्षशब्द बनाउनपई भन्ने अभिमत असी प्रतिशतभन्दा कम पैंसट्ठी प्रतिशतभन्दा माथि रहेको छ।

४. दुई शब्दमध्ये एकलाई मात्र शीर्ष बनाउनुपईई भन्ने अभिमतको प्रतिशत अन्तर २५ र सोभन्दा कम भएका जम्मा आठ जोडी शब्द रहेका छन् : अधिदेव/अधिदेवता, उछितो/उछितो, उलटपलट/उलटपुलट, नसियत/नसिहत, पट्याङ्ग/पट्याड्ड, पथ्रेन/पथ्य्रान, परमार्द्ध/परमार्थ र मसोट/मसौट रहेका छन् ।

\section{सुकाव}

प्रस्तुत अध्यनयबाट प्राप्त भएका प्रतिक्रिया तथा निष्कर्षका आधारमा देहायबमोजिम सुकाव पेस गर्न सकिन्छ :

नुमना जनसड्य्याले दिएको अभिमतका लागिका आधारमा शतप्रतिशत सकारात्मक अभिमत प्राप्त भएका आठ ओटा शब्द उपियाँ, छात्रावास, धसिङ्गर, नाउर, पाउजु, बाइबल, रेकर्ड र सरिता शब्दलाई निशङ्कोच निर्विकल्प शीर्षशब्दमा चयन गर्नु नै उपयुक्त हुन्छ। असी प्रतिशत वा सोभन्दा बढ़ी प्रतिशतले सकारात्मक प्रतिक्रिया जनाएका अगेनो, अधिगमन, अनिच्छुक, अन्तर्मुखी, अप्ठ्यारो, उल्फा, किचिमिची, खच्चड, छानो, जेब, नवरात्री, नसिब, भक्कानो, भक्त, यष्टि, राडो, रोमावली, सरिफ शब्दलाई पनि निर्विकल्प शीर्षशब्द नै बनाउन सकिन्छ । ठेट्नो, गुलाब, मतपेटिका, धपेडी, धर्माध्यक्ष तथा अखानो शब्दलाई पुन: छलफल तथा अनुसन्धानका आधारमा शीर्षीकरण गर्नु उपयुक्त हुन्छ भने आठ जोडी शब्द : अधिदेव/अधिदेवता, उछितो/उछ्छितो, उलटपलट/उलटपुलट, नसियत/नसिहत, पट्याड्ग्ग/पट्याड्ड, पथ्रेन/पथ्य्रान, परमार्द्ध/परमार्थ र मसोट/मसौट लाई गहन अध्ययन, विज्ञहरूबिचको अन्तर्किया एवम् थप अनुसन्धानबाट पुनरावलोकन गरी कुनै एक शब्दलाई शीर्ष बनाउनु उपयुक्त हुन्छ।

यसरी शब्दकोशका प्रयोक्ता तथा कोशशास्त्रका अध्येतासँग लिइएको अभिमतका आधारमा नेपाली बृहत् कोशमा विकल्पमा राखिएका शब्द हटाउनु नै उपयुक्त हुन्छ। एक शब्दको प्रविष्टिका लागि यस्ता विविधता 
नेपाली बृहत शब्दकोशका शीर्षशब्दमा वैकल्पिक प्रविष्टिको सान्दर्भिकता / 135

भएका शब्दका सम्बन्धमा बृहत् अध्ययन तथा अनुसन्धान गरी निर्णय लिनु आवश्यक छ। शब्दकोशमा एउटा शब्दको शीर्षीकरणतर्फ सम्बन्वित सरोकारवाला अभिमुख हुनु अनिवार्य छ भन्ने निष्कर्ष यस अध्ययनबाट प्राप्त भएको छ। विकल्पमा दिइएका शब्द उच्चारण भेद, भाषिका भेद, स्रोत भेद आदिका रूपमा रहेको हुन सक्ने हुँदा प्रयोजनअनुसार प्रतिनिर्देशबाट वा अन्य विधिबाट प्रस्ट्याउन सकिन्छ। त्यस्तै, प्रतिनिर्देश वा अन्य विधिबाट सूचीकृत गर्न सकिन्छ र आवश्यक सूचना दिन पनि सकिन्छ। पहिचान दिन सकिन्छ तर वैकल्पिक शब्दका रूपमा प्रविष्टि दिनु उपयुक्त हुँदैन ।

\section{सन्दर्भ सामग्री}

अधिकारी, हेमाड्गराज र भट्टराई, बद्रीविशाल (२०६१), प्रयोगात्मक नेपाली शब्दकोश, काठमाडौं : विद्यार्थी पुस्तक भण्डार ।

अधिकारी, हेमाड्गराज (२०६२), सामाजिक र प्रायोगिक भाषाविज्ञान, काठमाडौं : रत्न पुस्तक भण्डार । अलि, जे. जी. (सन् 9९९६), वेव्स्टर्स डिक्सनरी, युएसए : ओटेन्हेइमर पब्लिसर्स । खनाल, पेशल (२०७७), शैक्षिक अनुसन्धान पद्धति, काठमाडौं : सनलाइट पब्लिकेसन । खनाल, राजेन्द्र (२०७६), प्रायोगिक भाषाविज्ञानका प्रमुख क्षेत्र, काठमाडौं : सनलाइट पब्लिकेसन । नेपाल प्रज्ञा प्रतिष्ठान (२०७४), नेपाली बृहत् शब्दकोश, काठमाडौं : नेपाल प्रज्ञा प्रतिष्ठान । नेपाल प्रज्ञा प्रतिष्ठान (२०५६ ), नेपाली वृहत् शब्दकोश, काठमाडौँ : नेपाल प्रज्ञा प्रतिष्ठान । पौडेल, माधवप्रसाद (२०६९), प्रायोगिक भाषाविज्ञानका प्रमुख आयामहरू, काठमाडौं : हेरिटेज पब्लिसर्स एन्ड डिस्ट्रिब्युटर्स ।

लम्साल, रामचन्द्र (२०४७७), कोशविज्ञान र नेपाली कोश, काठमाडौं : विद्यार्थी पुस्तक भण्डार ।

व्हमर, एस्., मेकोन्टस्. सि. एन्ड टर्नबुल, जे. (सन्. २००४), अक्सफोर्ड अड्भभान्स्ड लर्नर्स डिक्नरी, न्युयोर्क : अक्सफोर्ड युनिभर्सिटी प्रेस । 